\title{
Caffeine Decreases Glial Cell Number and Increases Hyaluronan Secretion in Newborn Rat Brain Cultures
}

\author{
STÉPHANE MARRET, BERTRAND DELPECH, NICOLE GIRARD, ANNIE LEROY, \\ CATHERINE MAINGONNAT, JEAN-FRANÇOIS MENARD, AND CLAUDE FESSARD \\ Laboratoire d'Oncologie Moléculaire, Centre Henri-Becquerel [S.M., B.D., N.G., C.M.J; Service de Médecine \\ Néonatale [S.M., C.F.]; Laboratoire de Biochimie [A.L.]; and Laboratoire de Biophysique [J.-F.M.], Centre \\ Hospitalier-Universitaire, 76000 Rouen, France
}

\begin{abstract}
Newborn rat brain astrocytes (type 1 astrocytes, O-2A progenitor cells, and O-2A progenitor-derived cells, i.e. oligodendrocytes and type 2 astrocytes) were cultivated to investigate the effect of addition of caffeine to the culture medium on glial cell development and secretion of hyaluronan (hyaluronic acid, HA). HA is a glycosaminoglycan, secreted by type 1 astrocytes especially, which is a major component of the extracellular matrix of immature brain involved in morphogenesis and differentiation. Caffeine was added to the culture medium of primary glial cell cultures at concentrations of $102 \mu M(20 \mathrm{mg} / \mathrm{L})$ or $255 \mu \mathrm{M}(50 \mathrm{mg} / \mathrm{L})$, considered therapeutic and toxic levels, respectively, in human newborns. HA was measured in the culture medium by immunoenzyme assay using sheep brain hyaluronectin, a glycoprotein that exhibits a strong affinity for $\mathrm{HA}$, as probe. In primary glial cell cultures, $102 \mu \mathrm{M}(20 \mathrm{mg} / \mathrm{L})$ caffeine had no visible effect on cell number or on HA secretion. At $255 \mu \mathrm{M}(50 \mathrm{mg} / \mathrm{L})$, there was a significant reduction of cell number (i.e. type 1 astrocytes, 0-2A progenitor cells, and progenitor-derived cells) and a significant increase of $\mathrm{HA}$ secretion per cell. These results suggest that caffeine at a high concentration in brain could have a prejudicial effect on the number of proliferating glial cells (astrocytes and oligodendrocytes) and on the composition of the extracellular matrix, which could affect myelination onset. (Pediatr Res 34: 716-719, 1993)
\end{abstract}

Abbreviations

HA, hyaluronan

HN, hyaluronectin

ECM, extracellular matrix

GFAP, glial fibrillary acidic protein

Galc, galactosylcerebroside

MEM, minimum essential medium

HBSS, Hanks' balanced salt solution

Methylxanthines (i.e. theophylline and caffeine) are widely used in premature newborns for the management of apnea (1). Possible efficacy has been reported in bronchopulmonary dysplasia (2) and in weaning premature infants from mechanical ventilation (3). Plasma therapeutic concentrations of $80-110 \mu \mathrm{M}$

Received August 6, 1992; accepted July 13, 1993.

Correspondence and reprint requests: S. Marret, Laboratoire d'oncologie moléculaire, Centre Henri-Becquerel, Rue d'Amiens, 76000 Rouen, France.

Supported by research grants from the Institut National de la Santé et de la Recherche Médicale (CNEP 90 CN 66) and the University of Rouen. caffeine have been suggested (1) and have been found to be free of immediate clinical side effects $(4,5)$ or short-term neurologic sequelae (6) in the premature infants. Nevertheless, methylxanthines diffuse easily through the blood-brain barrier (7), reduce cerebral blood flow (8-11), and increase oxygen consumption in neonates (12). They have some potentially deleterious metabolic effects: antagonism of adenosine, a nucleoside involved in many aspects of glial cell and neuron metabolism (13); inhibition of cholesterol synthesis, an important component of the cellular membrane in cultured glial cells (14); and decrease in the activity of cerebroside sulfotransferase, a key enzyme in myelination (15).

In immature brain, glial cells are still proliferating and play an important role in the secretion of the ECM macromolecules: laminin, fibronectin $(16,17)$, and glycosaminoglycans $(18,19)$. HA is one of these glycosaminoglycans, and it has an important role in the developing brain. It is a natural substrate upon which cells migrate and proliferate in vivo. Subsequent differentiation is accompanied by a decrease of HA level in the ECM (19).

The purpose of our study was to investigate the effects of caffeine on glial development and HA secretion in newborn rat brain glial cell cultures. The affinity of $\mathrm{HN}$, a brain HA-binding glycoprotein (20), was used for the quantification of HA secretion in the medium.

\section{MATERIAL AND METHODS}

Materials. Female Wistar rats were housed in groups and fed laboratory rat food and water ad libitum in the Centre Henri Becquerel facilities.

MEM with $\alpha$-ribonucleosides and HBSS (10x) were obtained from GIBCO (Cergy-Pontoise, France). FCS, HBSS $(1 \times)$ with $(+)$ and without $(-)$ calcium and magnesium salts, and trypsin (1X) were purchased from Eurobio (Paris, France); BSA from Sigma (la Verpilière, France), Superose 6 column for HPLC from Pharmacia (les Ulis, France), and HA from Fluka (Mulhouse, France). Antiserum to sheep $\mathrm{HN}$ was raised in rabbits, and sheep brain HN was purified as described previously (21, 22). Monoclonal anti-GFAP antibody was purified in the laboratory (23). Mouse monoclonal A2B5 was obtained from the American Type Culture Collection (Rockville, MD). Rabbit polyclonal antigalactocerebroside antibody (anti-Galc) was kindly donated by Dr. Hiroaki Asou (Tokyo, Japan) and by Dr. Bernard Zalc (Paris, France). Goat polyclonal antihuman von Willebrand factor was from Biorad (Ivry-sur-Seine, France), and mouse monoclonal anti-type 3 complement receptor IgG2 A (OX-42) was from Serotec (Paris, France). Fluorescein-conjugated goat antirabbit and sheep antimouse IgG antibodies were from Institut Pasteur (Marnes-la-Coquette, France), Texas redconjugated sheep antimouse IgG antibodies from Amersham 
(Les Ulis, France), and Texas red-conjugated donkey antigoat IgG antibodies and alkaline phosphatase-conjugated donkey anti-rabbit IgG antibodies from Jackson Immunoresearch Laboratories (Interchim, Montluçon, France). Other chemical products of analytical grade were from Merck (Paris, France). Microtest plates were from Nunc (Poly Labo Paul Block, Strasbourg, France), and tissue culture flasks and plates were from Falcon (Poly Labo Paul Block). Caffeine ( $1 \mathrm{~mL}=10 \mathrm{mg}$ ) was purchased from Meram (Paris, France). The kit for caffeine immunoassay was from Syva Company (Lyon, France).

Methods. Primary glial cell cultures. Primary glial cell cultures were established using the method of MacCarthy and de Vellis (24). Three male or female pups of one litter were killed by decapitation within a few hours after birth. Both hemispheres were removed from one cerebrum. Meninges were dissected off to avoid dural and meningeal contamination in HBSS (+) at room temperature. Brain cells were dissociated mechanically with a syringe and a 2-mm diameter needle in MEM and allowed to settle for $5 \mathrm{~min}$ at room temperature. The supernatant was discarded, and the pellet was resuspended in MEM and redissociated twice. Supernatants were pooled and centrifuged $(800$ rpm, $10 \mathrm{~min}, 4^{\circ} \mathrm{C}$ ). Cells were counted on a hemocytometer and plated in 12-well plates at a density of $7.5 \times 10^{5}$ cells $/ \mathrm{mL}$. Cultures were maintained in a humidified incubator at $37^{\circ} \mathrm{C}$ gassed with $5 \% \mathrm{CO}_{2}$. Medium was changed every $3 \mathrm{~d}$.

Caffeine. All the cultures were done in standard conditions as described above and in medium supplemented with caffeine. Because in vivo it diffuses integrally through the blood-brain barrier (7), caffeine was added to obtain a concentration of 102 $\mu \mathrm{M}(20 \mathrm{mg} / \mathrm{L})$ or $255 \mu \mathrm{M}(50 \mathrm{mg} / \mathrm{L})$, which are considered therapeutic and toxic levels, respectively, in the human newborn (1). Caffeine was added to MEM every $3 \mathrm{~d}$ when MEM was changed. Caffeine concentration in medium was measured with the immunoenzyme assay.

Immunostainings. Immunostainings were performed to recognize the different cell types of glial lineage (25). To detect GFAP, cultures were fixed in acetone for $10 \mathrm{~min}$ and labeled with a monoclonal anti-GFAP antibody (undiluted supernatant). Fluorescein-conjugated second antibody $(1: 20)$ was used. To detect A2B5 and Galc antigens, cultures were fixed in $2.5 \%$ pformaldehyde in PBS for 8-10 $\mathrm{min}$ and were incubated with A2B5 antibody (1:10) or anti-Galc antibody (1:10) for $30 \mathrm{~min}$. Texas red-conjugated second antibody $(1: 30)$ was used after A2B5 antibody, and fluorescein-conjugated second antibody (1:20) after anti-Galc antibody.

Coverslips were mounted on slides and observed with a microscope equipped with epifluorescence objectives (Leitz). Glial phenotypes in primary glial cell cultures were defined as follows: 1) large, flat cell without visible cell process in confluent cultures, A2B5 (-), GFAP (+): type 1 astrocyte; 2) small-size cell with fine cell processes and dark body resting on the top of a bed layer of type 1 astrocytes, A2B5 $(+)$, GFAP $(-)$ : O-2A progenitor cell; 3 ) small cell with long processes A2B5 $(+)$, GFAP $(+)$ : type2 astrocyte; and 4) small stellate cell with a refringent body and numerous very fine processes, Galc (+): oligodendrocyte. Immunostainings were performed also to recognize endothelial cells and microglial cells. The rare occurrence of microglial cells and the absence of endothelial cells were detected with OX-42 (1:100) and with antihuman von Willebrand factor $(1: 80)$, respectively.

HA immunoenzyme assay. Supernatant HA concentration was determined by the indirect immunoassay using sheep brain HN $(21,22) . \mathrm{HN}$ is a glycoprotein extracted from brain that binds to HA but not to other glycosaminoglycans (20) and can be used as a probe for a quantitative estimation of HA. Plastic microtest plates with 96 wells were coated with a $100 \mathrm{mg} / \mathrm{L} \mathrm{HA}$ in $0.1 \mathrm{M}$ bicarbonate with $0.2 \mathrm{~g} / \mathrm{L}$ sodium azide. Samples of culture medium were preincubated during $1 \mathrm{~h}$ in a test tube with a 30$\mu \mathrm{g} / \mathrm{L}$ sheep brain HN solution. Samples were incubated on HAcoated microtest plates for $4 \mathrm{~h}$. Maximum sensitivity was achieved when incubation was carried out at $4^{\circ} \mathrm{C}$. $\mathrm{HN}$ bound to the plate was revealed after a $1-h$ incubation with immune complexes obtained by mixing anti-sheep HN IgG $(1: 2000)$ and alkaline phosphatase-conjugated donkey anti-rabbit globulin antibodies (1:5000) in PBS with $0.2 \mathrm{~g} / \mathrm{L}$ sodium azide and $1 \mathrm{~g} / \mathrm{L}$ BSA. The phosphatase substrate was para-nitrophenyl phosphate $(1 \mathrm{~g} / \mathrm{L}$ in $1 \mathrm{M}$ diethanolamine equilibrated at $\mathrm{pH} 9.8$ by concentrated $\mathrm{HCl}$ and containing $0.001 \mathrm{M} \mathrm{MgCl}_{2}$ ). After a 1-h incubation with substrate at $37^{\circ} \mathrm{C}$, absorbance variations, a function of HA concentration, were recorded on a Titertek Multiskan instrument (Flow, Paris, France) at $405 \mathrm{~nm}$. The test is specific and could detect $1 \mu \mathrm{g} / \mathrm{L}$ HA. Specificity of the assay was verified by Streptomyces hyaluronidase digestion of sample. Recovery of HA was good and intra- and interassay variation coefficients were $6 \pm 2.2$ and $12 \%$, respectively. Comparison of six assays, developed in different laboratories, including ours, was done and showed results of the same magnitude (26).

A $10 \%$ FCS medium was used as control. For each sample, the HA concentration of the control was deducted from the HA concentration of the medium sample to obtain HA secretion. According to our previous results in cultures enriched by passage either in type 1 astrocytes or in total O-2.A lineage cells $(27,28)$, it has been demonstrated that HA was secreted into the medium by type 1 astrocytes but not by $\mathrm{O}-2 \mathrm{~A}$ progenitor and $\mathrm{O}-2 \mathrm{~A}$ progenitor-derived cells. Because type 1 astrocytes are by far the largest population of cells in primary glial cell cultures $(95 \%)$, we divided the HA sample concentration by the total glial cell number present in the corresponding well to have a secretion of HA per hour and per cell.

Cell counting. Upper small cells (i.e. O-2A progenitor and O$2 \mathrm{~A}$ progenitor-derived cells) present on the surface of the bottom bed layer of type 1 astrocytes in the cultures were counted on the phase contrast microscope, which was equipped with an ocular micrometer. Nine fields of $0.3 \mathrm{~mm}^{2}$ were counted in each well. Thereafter, medium was drawn off from wells. Cultures were rinsed with HBSS (-) for $15 \mathrm{~min}(1 \mathrm{~mL} /$ well $)$ and trypsinized for $8 \mathrm{~min}(0.5 \mathrm{~mL} /$ well). Cells were aspirated with a syringe and trypsinization was stopped by addition of MEM with $10 \%$ FCS $(2 \mathrm{~mL} /$ well). All glial cells (i.e. type 1 astrocytes, O-2A progenitor and $\mathrm{O}-2 \mathrm{~A}$ progenitor-derived cells) were counted on a hemocytometer.

HPLC. To characterize HA molecular size, HPLC was run in PBS through a Superose 6 column driven by Beckman equipment.

Statistics. A two-way analysis of variance was used to evaluate cell number or HA secretion as a function of time or phases of culture; when a significance was determined $(p<0.05)$, Newman Keuls test was performed post hoc to identify significant differences between means. Log values were used for statistical calculations. Measurements are reported as means $\pm \mathrm{SD}$.

\section{RESULTS}

Effect of caffeine on glial cell number (Fig. 1). In primary glial cell cultures, caffeine added into the medium at $102 \mu \mathrm{M}(20 \mathrm{mg} /$ L) had no effect on cell number: neither type 1 astrocytes nor O$2 \mathrm{~A}$ progenitor or $\mathrm{O}-2 \mathrm{~A}$ progenitor-derived cell numbers were altered compared with controls. In phase-contrast microscopy, there was no difference between cultures in control medium and cultures in medium with caffeine at $102 \mu \mathrm{m}(20 \mathrm{mg} / \mathrm{L})$. Flat GFAP $(+)$ type 1 astrocyte were confluent between $d 6$ and 9 and A2B $5(+) \mathrm{O}-2 \mathrm{~A}$ progenitor or $\mathrm{O}-2 \mathrm{~A}$ progenitor-derived cells were numerous on the top of the bed layer between $d 8$ and 10 . Caffeine at the concentration of $255 \mu \mathrm{M}(50 \mathrm{mg} / \mathrm{L})$ decreased the cell numbers. According to microscopic observation, confluence was obtained later (around d 12 and 15 instead of $d 6$ and 9 in control cultures). At the end of the experiments (d 18), the total number of glial cells (i.e. type 1 astrocytes, O-2A progenitor cells, and $\mathrm{O}-2 \mathrm{~A}$ progenitor-derived cells) was lower (30\%) in cultures with caffeine at $255 \mu \mathrm{M}(50 \mathrm{mg} / \mathrm{L})$ than in control cultures or in cultures with caffeine at $102 \mu \mathrm{M}(20 \mathrm{mg} / \mathrm{L})(30 \%)$ 


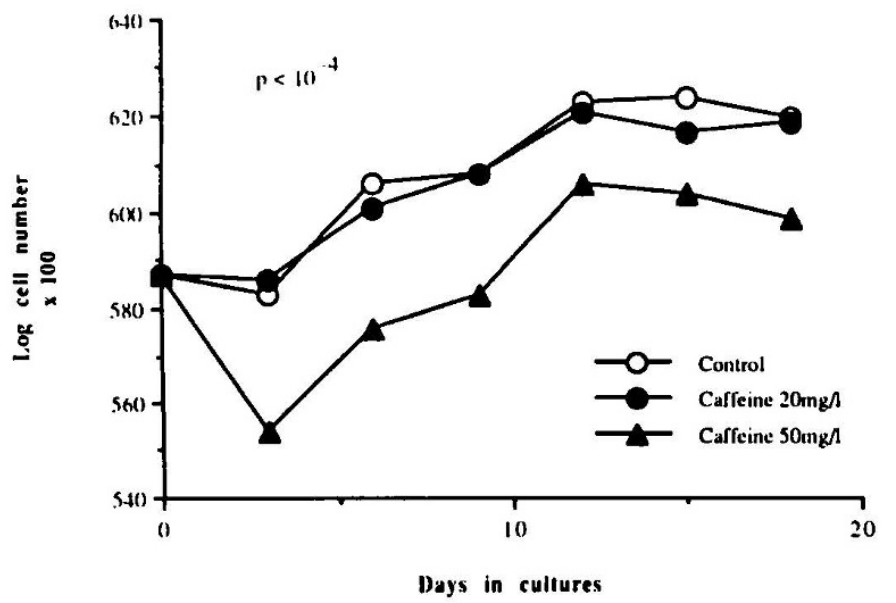

Fig. 1. Total glial cell number (i.e. type 1 astrocytes, O-2A progenitor cells, and progenitor-derived cells) in control cultures, cultures with caffeine at $102 \mu \mathrm{M}(20 \mathrm{mg} / \mathrm{L})$, and cultures with caffeine at $255 \mu \mathrm{M}(50$ $\mathrm{mg} / \mathrm{L}$ ), as a function of days in culture. Each number was the mean of five replicates. Analysis of variance: $p<10^{-4}$; cell numbers between days of culture and cell numbers between groups; Newman Keuls test: the difference between the number of the cells of $255 \mu \mathrm{M}(50 \mathrm{mg} / \mathrm{L})$ caffeine group and the $102 \mu \mathrm{M}(20 \mathrm{mg} / \mathrm{L})$ caffeine group or control group was significant $\left(p<10^{-4}\right)$.

Table 1. $O-2 A$ progenitor or $O-2 A$ progenitor-derived cell numbers (per $0.3 \mathrm{~mm}^{2}$ ) in phase-contrast microscopy

\begin{tabular}{lcl}
\hline & Day 6 & Day 18 \\
\hline Control & $115 \pm 18$ & $283 \pm 67$ \\
Caffeine $20 \mathrm{mg} / \mathrm{L}$ & $122 \pm 32$ & $250 \pm 47$ \\
Caffeine $50 \mathrm{mg} / \mathrm{L}$ & $50 \pm 32^{*}$ & $118 \pm 37^{*}$ \\
\hline
\end{tabular}

* Analysis of variance: $p<10^{-4}$ (d 6 and 18$)$.

(Fig. 1). The O-2A progenitor and O-2A progenitor-derived cell numbers (Table 1) were lower in cultures with caffeine at 255 $\mu \mathrm{M}(50 \mathrm{mg} / \mathrm{L})$ than in control cultures or cultures with $102 \mu \mathrm{M}$ $(20 \mathrm{mg} / \mathrm{L})$ caffeine $(40-50 \%)$.

Effect of caffeine on HA secretion. In primary cultures, whatever the day of culture, there was no significant difference in HA secretion per hour and per cell between controls and cultures with $102 \mu \mathrm{M}(20 \mathrm{mg} / \mathrm{L})$ caffeine (Fig. 2). However, in cultures with $255 \mu \mathrm{M}(50 \mathrm{mg} / \mathrm{L})$ caffeine, the HA secretion per hour and per cell was significantly higher than in controls.

In regard to the HA secretion results (Fig. 3) as a function of culture stage (logarithmic phase in which cells have the maximum proliferation, confluence phase, or overconfluence phase), in overconfluence phase, the HA secretion persisted at a significantly higher rate in cultures at $255 \mu \mathrm{M}(50 \mathrm{mg} / \mathrm{L})$ caffeine than in controls and cultures with $102 \mu \mathrm{M}(20 \mathrm{mg} / \mathrm{L})$ caffeine. In each group [control, $102 \mu \mathrm{M}(20 \mathrm{mg} / \mathrm{L})$ caffeine, $255 \mu \mathrm{M}(50 \mathrm{mg} / \mathrm{L})$ caffeine], the HA secretion was not significantly different between the logarithmic and confluence phases but was significantly decreased when the overconfluence phase was considered.

Caffeine assay. Caffeine assay in medium at $\mathrm{d} 3$ after the addition of $255 \mu \mathrm{M}(50 \mathrm{mg} / \mathrm{L})$ caffeine showed no significant reduction, inasmuch as caffeine was still present at $224 \mu \mathrm{M}$ (43 $\mathrm{mg} / \mathrm{L}$ ) concentration.

Characterization of HA molecular mass. HA molecular size was studied with HPLC. Glial cells without or with caffeine added to the medium produced essentially high molecular mass molecules mixed with a small proportion of smaller mass molecules.

\section{DISCUSSION}

In our in vitro study, we added caffeine to the culture medium at a concentration of $102 \mu \mathrm{M}(20 \mathrm{mg} / \mathrm{L})$ or $255 \mu \mathrm{M}(50 \mathrm{mg} / \mathrm{L})$,

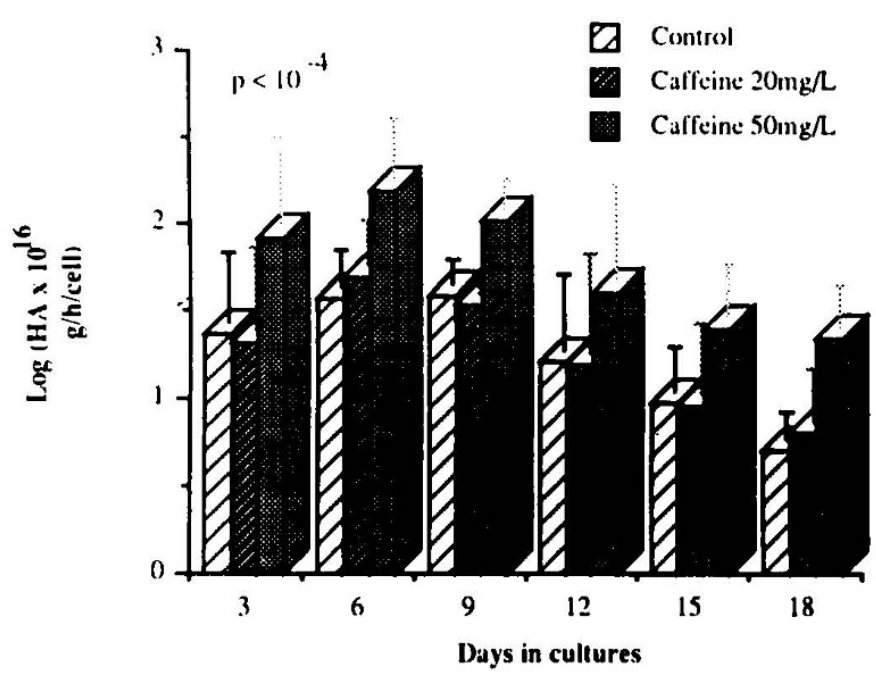

Fig. 2. HA production per hour and per cell in control cultures, cultures with caffeine at $102 \mu \mathrm{M}(20 \mathrm{mg} / \mathrm{L})$, and cultures with caffeine at $255 \mu \mathrm{M}(50 \mathrm{mg} / \mathrm{L})$, as a function of days in culture. Each number was the mean of five replicates. Analysis of variance: $p<10^{-4}$; HA production between days of culture and HA production between groups; Newman Keuls test: the difference was significant $\left(p<10^{-4}\right)$ between the $255 \mu \mathrm{M}$ $(50 \mathrm{mg} / \mathrm{L})$ caffeine group and the $102 \mu \mathrm{M}(20 \mathrm{mg} / \mathrm{L})$ caffeine group or the control group. The difference was not significant between the 102 $\mu \mathrm{M}(20 \mathrm{mg} / \mathrm{L})$ caffeine group and the control group.

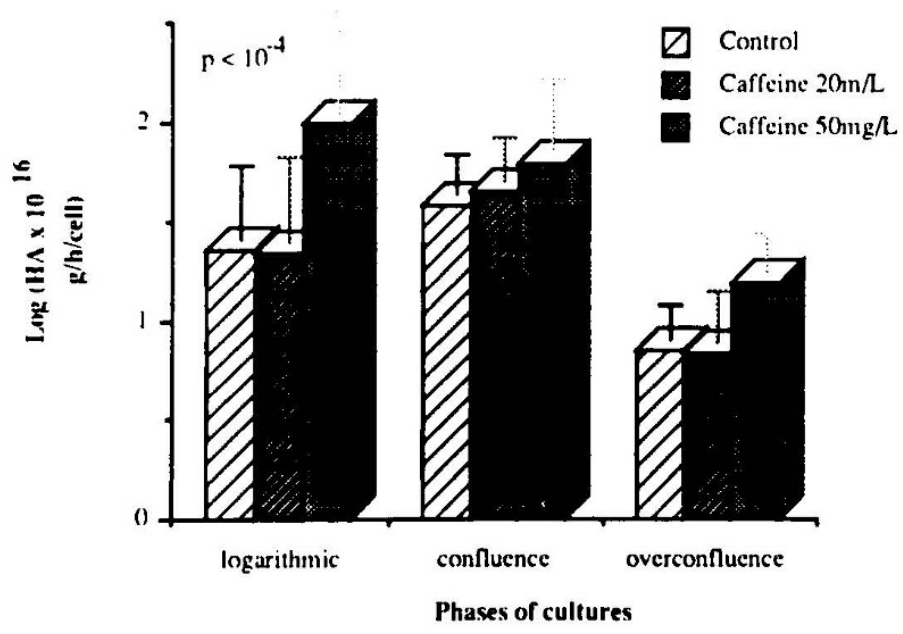

Fig. 3. HA production per hour and per cell in control cultures, cultures with caffeine at $102 \mu \mathrm{M}(20 \mathrm{mg} / \mathrm{L})$, and cultures with caffeine at $255 \mu \mathrm{M}(50 \mathrm{mg} / \mathrm{L})$, as a function of phases of culture. Each number was the mean of five replicates. Analysis of variance: $p<10^{-4}$; HA production between phases of culture and HA production between groups; Newman Keuls test: HA production was significantly higher in the $255 \mu \mathrm{M}(50 \mathrm{mg} / \mathrm{L})$ caffeine group $v s$ the $102 \mu \mathrm{M}(20 \mathrm{mg} / \mathrm{L})$ caffeine group or the control group $\left(p<10^{-4}\right)$. The difference was not significant between the $102 \mu \mathrm{M}(20 \mathrm{mg} / \mathrm{L})$ caffeine group and the control group.

which corresponds to in vivo therapeutic $(102 \mu \mathrm{M})$ and toxic $(255 \mu \mathrm{M})$ blood concentrations, respectively (1). It has been demonstrated that cerebrospinal fluid/blood and brain tissue/ blood $(7,29)$ caffeine ratios are close to or greater than 1 . Thus, blood concentrations are likely to represent concentrations to which glial cells are exposed in the immature human brain. The assay of caffeine in culture medium showed that no significant decay occurred within $3 \mathrm{~d}$ after the addition of caffeine.

We observed that caffeine at $102 \mu \mathrm{M}(20 \mathrm{mg} / \mathrm{L})$ had no deleterious effect on glial cell number, as also reported by Volpe (14). At the high concentration of $255 \mu \mathrm{M}(50 \mathrm{mg} / \mathrm{L})$, the number of glial cells of all types (type 1 astrocytes, O-2A lineage cells) was significantly reduced. The effect of caffeine at $255 \mu \mathrm{M}(50$ 
$\mathrm{mg} / \mathrm{L}$ ) could be either toxic or metabolic. Toxicity could affect a portion of cells, while another portion of them could continue to proliferate in cultures with caffeine at $255 \mu \mathrm{M}(50 \mathrm{mg} / \mathrm{L})$. In this way, some authors have noted that caffeine induced an uncoupling of mitosis from the completion of DNA replication in mammalian cells (30). Negative metabolic effects could also occur according to other reports: antagonism of adenosine (13), and decrease of fatty acids and cholesterol synthesis by means of hydroxymethylglutaryl-CoA reductase (14). The decreased number of glial cells could be prejudicial in the developing brain at a period when glial cell number is still increasing (14) and when the onset of myelination, built up by mature oligodendrocytes, O-2A progenitor-derived cells (25), is initiated.

At the higher dose, the HA secretion per cell was increased. $\mathrm{HA}$ is a highly hydrated molecule that is a main component of $E C M$, plays an important role in the developing brain (18), and acts to create a readily penetrable matrix through which neuroblast extension and migration take place. Differentiation is accompanied by a decrease of HA levels (18). HA produced in glial cell cultures was of high molecular weight. It was shown that high concentrations of high molecular mass HA inhibit vascularization and disrupt vascular integrity by direct action (31), and inhibit subendothelial cell proliferation in vitro (32). In previous in vitro studies $(27,28)$, we demonstrated that HA was secreted by type 1 astrocytes and acted on O-2A progenitor and $\mathrm{O}-2 \mathrm{~A}$ progenitor-derived cells. When $\mathrm{HA}$ was added to the culture medium, the higher the HA concentration, the lower the $\mathrm{O}-2 \mathrm{~A}$ progenitor cell and Galc (+) oligodendrocyte numbers, suggesting that $\mathrm{HA}$ had an important role in the $\mathrm{O}-2 \mathrm{~A}$ progenitor and subsequent oligodendrocyte formations. In vivo HA concentration in rat brain decreases dramatically at $\mathrm{d} 11$ after birth (33), suggesting that myelination, which begins in the rat brain at this moment (34), could be conditioned by a fall in type 1 astrocyte activity and HA concentration in the brain. The higher secretion of HA noticed in glial cultures in the presence of a high dose of caffeine $[255 \mu \mathrm{M}(50 \mathrm{mg} / \mathrm{L})]$ could have a negative effect on final $\mathrm{O}-2 \mathrm{~A}$ progenitor cell numbers and could delay or impair onset of myelination, which is usually initiated within the last months of pregnancy in the immature human brain and within $10 \mathrm{~d}$ after birth in rat brain. The effect on HA secretion could be either a direct effect on HA synthesis by cell, inasmuch as it was shown to cause some alterations of cell metabolism in other studies, or an indirect effect through cell number modification.

In conclusion, in vitro, caffeine at $255 \mu \mathrm{M}(50 \mathrm{mg} / \mathrm{L})$ gives rise to a decrease in glial cell population that parallels an increase in HA secretion by type 1 astrocytes, whereas with $102 \mu \mathrm{M}(20$ $\mathrm{mg} / \mathrm{L}$ ), caffeine culture behavior was similar to controls. In vivo studies on animals would be necessary to test the effect of caffeine on proliferation of glial cells and myelination.

Acknowledgments. The authors thank Dr. N. Moore for helpful discussion and manuscript revision.

\section{REFERENCES}

1. Aranda JV, Gorman W, Bergsteinsson H, Gunn T 1977 Efficacy of caffeine in treatment of apnea in the low-birth-weight infant. J Pediatr 90:467-472

2. Greenough A 1990 Bronchopulmonary dysplasia: early diagnosis, prophylaxis and treatment. Arch Dis Child 65:1082-1088

3. Durand DA, Goodman A, Ray P, Ballard RA, Clyman R 1987 Théophylline treatment in the extubation of infants weighing less than 1250 grams: a controlled trial. Pediatrics 80:684-688

4. Gerhardt T, McCarthy J, Bancalari E 1979 Effect of aminophylline on respiratory center activity and metabolic rate in premature infants with apnea. Pediatrics 63:537-542

5. Rall TW 1980 Central nervous system stimulants, the xanthines. In: Gilman
AG, Goodman LS, Gilman A (eds) The Pharmacological Basis of Therapeutics. MacMillan, New York, pp. 592-607

6. Gunn TR, Metrakos K, Riley P, Willis D, Aranda JV 1979 Sequelae of caffeine treatment in preterm infants with apnea. J Pediatr 94:106-109

7. Somani SM, Khanna NN, Bada HS 1980 Caffeine and theophylline: serum/ CSF correlation in premature infants. J Pediatr 96:1091-1093

8. Rosenkrantz TS, Oh W 1984 Aminophylline reduces cerebral blood flow velocity in low-birth weight infants. Am J Dis Child 138:489-491

9. Friis-Hansen B 1986 Cerebral blood flow in the newborn infant cardiovascular and respiratory physiology in the fetus and neonates. In: INSERM (ed) Cardiovascular and Respiratory Physiology in the Fetus and Neonate. John Libbey, Paris, pp 95-108

10. Pryds O, Schneider S 1991 Aminophylline reduces cerebral blood flow in stable, preterm infants without affecting the visual evoked potential. Eur $\mathrm{J}$ Pediatr 150:366-369

11. McDonnell M, Ives NK, Hope PL 1992 Intravenous aminophylline and cerebral blood flow in preterm infants. Arch Dis Child 67:416-418

12. Aranda JV, Chemtob S, Laudignon N, Sasyniuk 1986 Pharmacologic effects of theophylline in the newborn. J Allergy Clin Immunol 78:773-780

13. Chin JH 1989 Adenosine receptors in brain: neuromodulation and role in epilepsy. Ann Neurol 26:695-698

14. Volpe JJ 1981 Effects of methylxanthines on lipid synthesis in developing neurol systems. In: Oliver TK, Kirschbaum TH (eds) Seminars in Perinatology. Grune and Stratton, New York, pp 395-403

15. Siegrist HP, Burkart T, Hoffmann K, Wiesmann U, Herschkowitz N 1980 Theophylline reduces the activity of cerebroside-sulfotransferase, a key enzyme in myelination, in cell cultures from newborn mouse brain. Pediatr Res 14:1226-1229

16. Liesi P, Dahl D, Vaheri A 1983 Laminin is produced by early rat astrocytes in primary culture. J Cell Biol 96:920-924

17. Liesi P, Kikwood T, Vaheri A 1986 Fibronectin is expressed by astrocytes cultured from embryonic and early postnatal rat brain. Exp Cell Res 163:175-185

18. Margolis RU, Margolis RK, Chang LB, Preti C 1975 Glycosaminoglycans of brain during development. Biochemistry 14:85-88

19. Toole BP 1981 Glycosaminoglycans in morphogenesis. In: Hay ED (ed) Cell Biology of Extracellular Matrix. Plenum Press, New York, pp. 259-294

20. Delpech B, Halavent C 1981 Characterization and purification from human brain of hyaluronic acid-binding glycoprotein: hyaluronectin. J Neurochem 38:978-984

21. Delpech B, Bertrand P, Maingonnat C 1985 Immunoenzyme assay of the hyaluronic acid-hyaluronectin interaction: application to the detection of hyaluronic acid in serum of normal subjects and cancer patients. Anal Biochem 149:555-556

22. Delpech B, Maingonnat C, Delpech A, Maes P, Girard N, Bertrand P 1991 Characterization of a hyaluronic acid-binding protein from sheep brain comparison with human brain hyaluronectin. Int J Biochem 23:329-337

23. Courel MN, Girard N, Delpech B, Chauzy C 1986 Specific monoclonal antibodies to glial fibrillary acid protein. J Neuroimmunol 11:271-276

24. McCarthy KD, de Vellis J 1978 Alpha-adrenergic receptor modulation of betaadrenergic, adenosine and prostaglandin El increased adenosine $3^{\prime}-5^{\prime}$ cyclic monophosphate levels in primary cultures of glia. J Cyclic Nucleotide Res 4:15-26

25. Cameron RS, Rakic P 1991 Glial cell lineage in the cerebral cortex: a review and synthesis. GLIA 4:124-137

26. Lindqvist U, Chichibu K, Delpech B, Goldberg RL, Knudson W, Poole AR, Laurent TC 1992 Seven different assays of hyaluronan compared for clinical utility. Clin Chem 38:127-132

27. Marret S, Delpech B, Levesque H, Delpech A, Ma S-X. Chauzy C. Fessard C 1991 Hyaluronan synthesis by astrocytes in newborn rat brain cell cultures. Biol Cell 73:21

28. Marret S, Delpech B, Delpech A, Girard N, Fessard C 1992 Effects of hypoxia on glial progenitor O-2A in newborn rat brain cultures. Biol Neonate 62:295296

29. Neese AL, Soyka LF 1977 Toxicity and tissue distribution of aminophylline in neonatal and adult mice and rats. Pediatr Res 11:783

30. Schlegel R, Pardee AB 1986 Caffeine-induced uncoupling of mitosis from the completion of DNA replication in mammalian cells. Science 232:1264-1266

31. West DC, Kumar S 1989 Hyaluronan and angiogenesis. In: The Biology of Hyaluronan, Ciba Foundation Symposium 143. Wiley, Chichester, UK, pp 187-207

32. Banerjee SD, Toole BP 1992 Hyaluronan-binding protein in endothelial cell morphogenesis. J Cell Biol 119:643-652

33. Delpech B, Delpech A, Brückner G, Girard N, Maingonnat C 1989 Hyaluronan and hyaluronectin in the nervous system. In: The Biology of the Hyaluronan, Ciba Foundation Symposium 143. Wiley, Chichester, UK, pp 208-232

34. Mcllwain H, Bachelard HS 1971 Chemical and enzymic make-up of the brain development. In: Macllwain H, Bachelard HS (eds) Biochemistry and the Central Nervous System. Churchill Livingstone, London. pp 406-444 